\title{
Article \\ Phenanthroline Complexation Enhances the Cytotoxic Activity of the VO-Chrysin System
}

\author{
Agustin Actis Dato ${ }^{1}$, Luciana G. Naso ${ }^{1}$, Marilin Rey ${ }^{2}$, Pablo J. Gonzalez ${ }^{2}$, Evelina G. Ferrer ${ }^{1}$ \\ and Patricia A. M. Williams ${ }^{1, * \mathbb{D}}$
}

Citation: Actis Dato, A.; Naso, L.G.; Rey, M.; Gonzalez, P.J.; Ferrer, E.G.; Williams, P.A.M. Phenanthroline Complexation Enhances the Cytotoxic Activity of the VO-Chrysin System. Inorganics 2022, 10, 4. https://doi.org/10.3390/ inorganics 10010004

Academic Editor: Dinorah Gambino

Received: 9 December 2021

Accepted: 23 December 2021

Published: 28 December 2021

Publisher's Note: MDPI stays neutral with regard to jurisdictional claims in published maps and institutional affiliations.

Copyright: (C) 2021 by the authors. Licensee MDPI, Basel, Switzerland. This article is an open access article distributed under the terms and conditions of the Creative Commons Attribution (CC BY) license (https:// creativecommons.org/licenses/by/ $4.0 /)$.
1 Centro de Química Inorgánica (CEQUINOR, UNLP, CONICET), Departamento de Química, Facultad de Ciencias Exactas, Universidad Nacional de La Plata, Bv. 120 No 1465, La Plata CP B1906CXS, Argentina; a.actisdato@hotmail.com (A.A.D.); luciananaso504@hotmail.com (L.G.N.); evelina@quimica.unlp.edu.ar (E.G.F.)

2 Departamento de Física, Facultad de Bioquímica y Ciencias Biológicas, Universidad Nacional del Litoral and CONICET, Santa Fe S3000ZAA, Argentina; mrey@fbcb.unl.edu.ar (M.R.); pablogonzalez1979@gmail.com (P.J.G.)

* Correspondence: williams@quimica.unlp.edu.ar

\begin{abstract}
Metal complexation in general improves the biological properties of ligands. We have previously measured the anticancer effects of the oxidovanadium(IV) cation with chrysin complex, $\mathrm{VO}$ (chrys) $)_{2}$. In the present study, we synthesized and characterized a new complex generated by the replacement of one chrysin ligand by phenanthroline (phen), $\mathrm{VO}$ (chrys)phenCl, to confer high planarity for DNA chain intercalation and more lipophilicity, giving rise to a better cellular uptake. In effect, the uptake of vanadium has been increased in the complex with phen and the cytotoxic effect of this complex proved higher in the human lung cancer A549 cell line, being involved in its mechanisms of action, the production of cellular reactive oxygen species (ROS), the decrease of the natural antioxidant compound glutathione (GSH) and the ratio GSH/GSSG (GSSG, oxidized GSH), and mitochondrial membrane damage. Cytotoxic activity studies using the non-tumorigenic HEK293 cell line showed that [VO(chrys)phenCl] exhibits selectivity action towards A549 cells after $24 \mathrm{~h}$ incubation. The interaction with bovine serum albumin (BSA) by fluorometric determinations showed that the complex could be carried by the protein and that the binding of the complex to BSA occurs through $\mathrm{H}$-bond and van der Waals interactions.
\end{abstract}

Keywords: oxidovanadium(IV) phenantrholine chrysin; vanadium cellular uptake; anticancer; albumin interaction

\section{Introduction}

Chrysin (Scheme 1) is a natural polyphenol with several biological activities, such as antioxidant, anticancer, antiviral, and neuroprotective. It has low solubility at physiological conditions, low bioavailability, quick metabolism, and rapid excretion, limiting its utilization as a chemotherapeutic agent [1]. Hence, its structure has been modified (by functionalization or metal complexation) in order to improve its bioactivities. Metal-based drug development is a promising strategy for the enhancement of the pharmacological action of drugs. In particular, vanadium complexes have been recognized to display biological activities for the treatment of various diseases, such as diabetes, cancer, tuberculosis, and leishmaniasis [2]. Cancer is one of the primary causes of mortality. Moreover, lung cancer is the main cause of cancer deaths. Recently, with the knowledge of the molecular mechanisms related to this disease, it has been found that angiogenesis is one of the causes of its bad prognosis $[3,4]$. 
<smiles></smiles>

Scheme 1. Draw of the structure of chrysin.

We have previously studied the anticancer behavior of chrysin and chrysin oxidovanadium(IV) metal complex on osteoblast like cells [5], breast cancer cells [6], and human lung A549 cancer cells [7] and showed that complexation improved the biological effects of the polyphenol. The selection of the heterocyclic base phenanthroline (phen) included as a second ligand is related to the fact that planar ligands coordinated to metals could bind DNA through intercalation to base pairs, improving the anticancer action of binary complexes, as well as confer lipophilicity to the compounds [8]. Only a few ternary chrysin metal complexes were reported and the $\mathrm{Ga}(\mathrm{III}), \mathrm{Cu}(\mathrm{II})$, and $\mathrm{Ru}(\mathrm{II})$-chrysin-ancillary aromatic chelator systems proved more cytotoxic than free chrysin in different cancer cell lines [9-11].

In the current work, we design the heteroleptic [ $\mathrm{VO}$ (chrys)phenCl] complex aiming to enhance the biological behavior of the $\mathrm{VO}$ (chrys) ${ }_{2}$ complex. It was characterized in the solid state and in solution. The biological activity of the complex as an anticancer drug was studied in the human lung cancer cell line A549 and toxicity was evaluated in the cell line derived from human embryonic kidney HEK293. The mechanism of action was studied by means of cellular reactive oxygen species (ROS) generation, natural antioxidant level depletion (glutathione, GSH), mitochondrial membrane damage, and vanadium cellular uptake. The interaction of the complex with BSA was also determined.

\section{Results}

\subsection{Synthesis of [VO(chrys)phenCl]}

The complex was prepared by the replacement of one ligand chrysin in the binary $\left[\mathrm{VO}(\text { chrys })_{2} \mathrm{EtOH}\right]_{2}$ complex by phen. The molar conductance of the complex measured in DMSO, $\Lambda_{\mathrm{m}}=11\left(\Omega^{-1} \mathrm{~cm}^{2} \mathrm{~mol}^{-1}\right)$, suggested a non-electrolyte compound. The thermogravimetric analysis (oxygen atmosphere, $50 \mathrm{~mL} / \mathrm{min}$ ) showed that the complex is stable up to $260{ }^{\circ} \mathrm{C}$, indicating that no solvation or coordination solvent molecules are present in the complex (Figure 1). The compound degraded in a series of two consecutive TG steps observed at 295 and $400{ }^{\circ} \mathrm{C}$. Weight constancy is attained at $525^{\circ} \mathrm{C}$ and the weight of the remaining solid residue, collected at $700{ }^{\circ} \mathrm{C}$, was $17.2 \%$, in good agreement with the expected value of $17.0 \%$. The presence of $\mathrm{V}_{2} \mathrm{O}_{5}$ in the residue was confirmed by FTIR spectroscopy. More details can be found in Section 4.

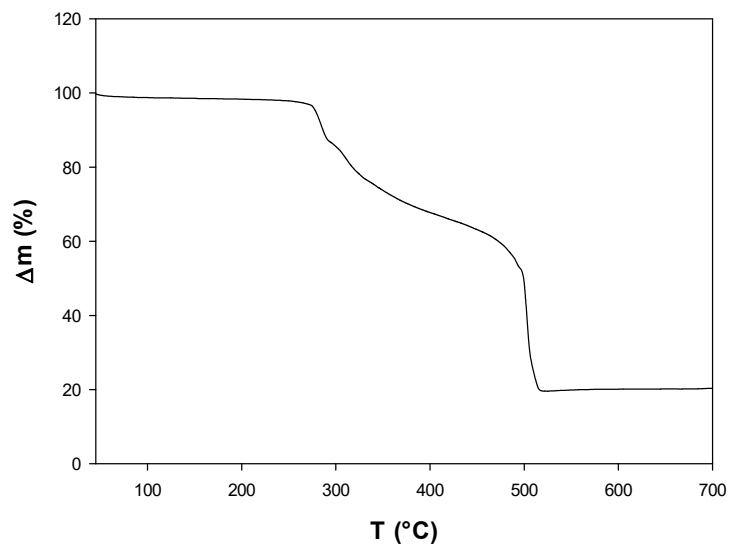

Figure 1. Thermogravimetric analysis (TGA) curve for the decomposition of [VO(chrys)phenCl]. 


\subsection{FTIR Spectrum}

The assignment of the main absorption bands of the FTIR spectrum of the complex was performed in comparison with the binary $\mathrm{VO}$ (chrys) ${ }_{2}$ system [5]. The spectral pattern remained similar to the binary compound regarding the modifications of the vibrational bands of $\mathrm{C}=\mathrm{O}$ stretching $\left(1635 \mathrm{~cm}^{-1}\right)$ and $\mathrm{O}-\mathrm{H}$ bendings $\left(1596,1351\right.$, and $\left.1247 \mathrm{~cm}^{-1}\right)$, indicating the coordination of chyrsin to the metal center (Figure 2). The vibrational modes of phen in the $1600-1400 \mathrm{~cm}^{-1}$ range (medium intensities) are associated with $C=C$ and $\mathrm{C}=\mathrm{N}$ stretching modes. These bands appeared to be overlapped with those of chrysin. However, it can be seen that the $\mathrm{C}=\mathrm{N}$ stretching band of phen at ca. $1646 \mathrm{~cm}^{-1}$ shifted to $1635 \mathrm{~cm}^{-1}$ upon coordination, but it is masked by the $\mathrm{C}=\mathrm{O}$ stretching mode (strong intensity) of the ligand chrysin. Main bands of motion of ring hydrogen atoms in phase and out of phase for phen at 852 and $738 \mathrm{~cm}^{-1}$, respectively, shifted to 847 and $725 \mathrm{~cm}^{-1}$, showing that phen is also interacting to the oxidovanadium(IV) cation [12].

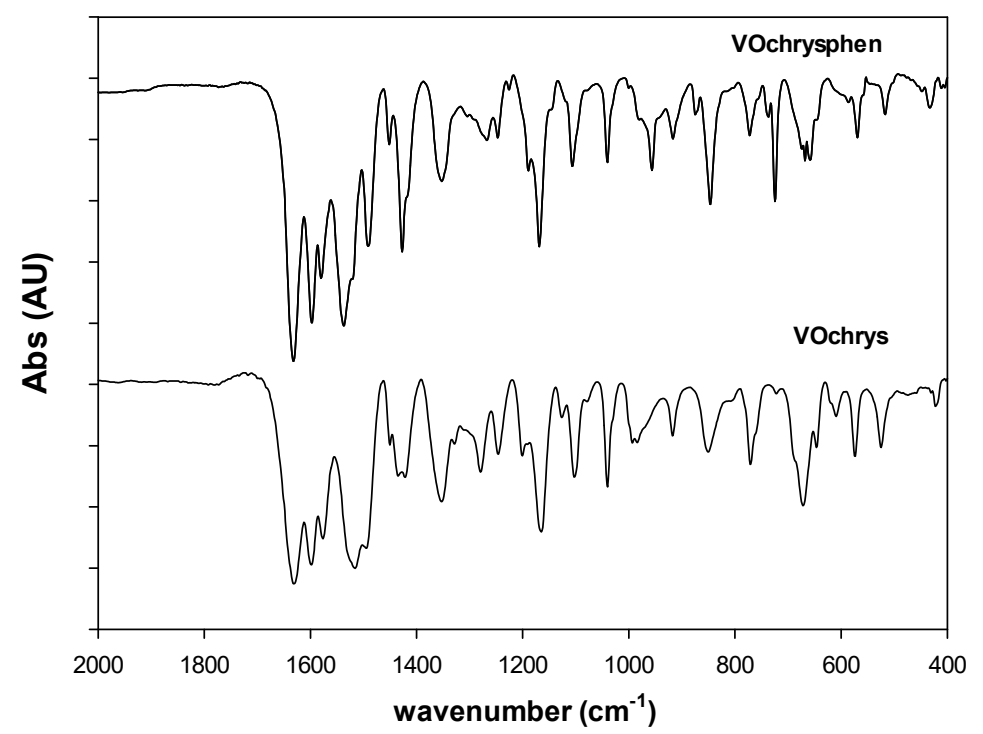

Figure 2. FTIR spectra of [VO(chrys)phenCl] and $\left[\mathrm{VO}(\text { chrys })_{2} \mathrm{EtOH}\right]_{2}$.

Moreover, the replacement of one chrysin ligand by one phen may produce a decrease of $\pi$ electron donation to the $\mathrm{V}=\mathrm{O}$ moiety. The shift of the $\mathrm{V}=\mathrm{O}$ stretching band from 968 to $957 \mathrm{~cm}^{-1}$ is indicative of a decrease of the bond order and an increase of the bond length in agreement with the ligand replacement. These results suggest that the metal ion is interacting with chrysin through $\mathrm{C}=\mathrm{O}$ and the deprotonated $\mathrm{C}(5)-\mathrm{O}$ group and with the $\mathrm{N}$ atoms of phen.

\subsection{EPR Measurements}

The powder EPR spectrum of the complex obtained at $120 \mathrm{~K}$ is shown in Figure 3. A very similar spectrum was obtained at room temperature (Figure S1A). The EPR spectrum of a polycrystalline powder of [ $\mathrm{VO}(\mathrm{chrys})$ phenCl] gave a unique EPR line, which does not show the typical eight line hyperfine splitting pattern of ${ }^{51} \mathrm{~V}$ nucleus $(I=7 / 2)$, suggesting the presence of extended spin-spin interactions between neighboring oxidovanadium(IV) ions in the solid complex, which collapse the hyperfine interaction into a single line [13]. Similar behavior was observed for oxidovanadium(IV) complexes of apigenin, naringenin, and quercetin [14-16] and it is characteristic of magnetically extended systems of the cation. 


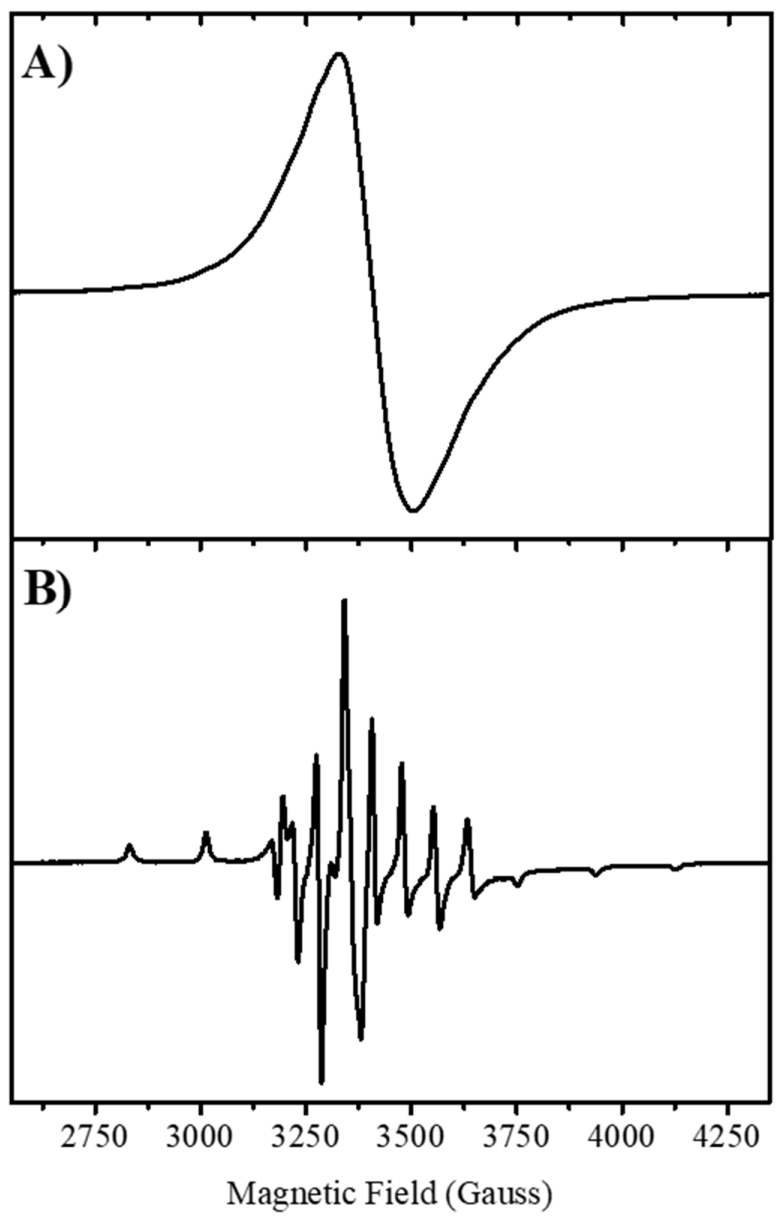

Figure 3. EPR spectrum of [VO(chrys)phenCl] recorded at $120 \mathrm{~K}$. (A) Powder sample and (B) Frozen DMSO solution. EPR spectra were recorded in a Bruker EMX-Plus spectrometer equipped with a rectangular cavity. Experimental conditions: $100 \mathrm{kHz}$ modulation, $4 \mathrm{Gpp}$ modulation amplitude, $2 \mathrm{~mW}$ microwave power.

The EPR spectrum of the DMSO frozen solution measured at $120 \mathrm{~K}$ displays the typical eight-line pattern spectrum for axial-V(IV) systems, as shown in Figure 3. The simulation (see Figure S1B) predicted that the observed signal was consistent with the oxidovanadium(IV) ion in a nearly axial or pseudoaxial ligand field. The spin Hamiltonian parameters and the hyperfine coupling constants were $\mathrm{g}_{\mathrm{II}}=1.941 ; \mathrm{A}_{\mathrm{II}}=162.2 \times 10^{-4} \mathrm{~cm}^{-1}$; $\mathrm{g}_{\perp}=1.977 ; \mathrm{A}_{\perp}=59.5 \times 10^{-4} \mathrm{~cm}^{-1}$. These parameters fit well in the corresponding $\mathrm{g}_{\mathrm{II}}$ vs. $A_{\text {II }}$ diagram for a $2 \mathrm{~N}, 2 \mathrm{O}$ coordination sphere [17]. Because the parallel component of the hyperfine coupling constant is sensitive to the type of donor atoms on the equatorial positions of the coordination sphere, the empirical relationship $A_{z}=\sum n_{i} A_{z, i}$ is frequently used to determine the identity of the equatorial ligands in V(IV) complexes $\left(\mathrm{n}_{\mathrm{i}}\right.$, number of equatorial ligands of type $i$ and $A_{z, i}$, the contribution to the parallel hyperfine coupling from each of them) [17]. Considering the contributions to the parallel hyperfine coupling constant of the different coordination modes $\left(\mathrm{CO}=44.7 \times 10^{-4}, \mathrm{ArO}^{-}=38.6 \times 10^{-4}\right)$ [14], and $\mathrm{N}$ (phen) $\times 2=40.4 \times 2 \times 10^{-4}$ [18], the calculated value for $\mathrm{A}_{\mathrm{II}}$ of $164.1 \times 10^{-4} \mathrm{~cm}^{-1}$ agrees with the experimental value. From the EPR parameters, we conclude that the coordination sphere would correspond to a binding mode of $\left(\mathrm{CO}, \mathrm{O}^{-}, 2 \mathrm{~N}\right)$ in the equatorial plane. The chloride ion that also linked to the metal center (see below) may be located in trans-position. Besides, it is observed that $\mathrm{g}_{\|}<\mathrm{g}_{\perp}<\mathrm{g}_{\mathrm{e}}=2.0023$ and $\left|\mathrm{A}_{\|}\right|>\left|\mathrm{A}_{\perp}\right|$, in line with an octahedral site with tetragonal compression and the $\mathrm{d}_{\mathrm{xy}}$ orbital being the ground state of the $\mathrm{V}^{4+}\left(3 \mathrm{~d}^{1}\right)$ ion. Moreover, the $\Delta \mathrm{g}_{\|} / \Delta \mathrm{g}_{\perp}$ ratio $\left(\left[\mathrm{g}_{\|}-\mathrm{g}_{\mathrm{e}}\right] /\left[\mathrm{g}_{\perp}-\mathrm{g}_{\mathrm{e}}\right]\right)$ proved to be 2.37, showing an octahedral tetragonal distortion. 
The hyperfine coupling constants were related to the dipolar hyperfine coupling parameter $\mathrm{P}$, that represents the dipole-dipole interaction of the electronic and nuclear moments, through the relations of Kivelson and Lee [19]: $\mathrm{A}_{\|}=-\mathrm{P}\left[\mathrm{k}+4 / 7-\Delta \mathrm{g}_{\|}-3 / 7 \Delta \mathrm{g}_{\perp}\right]$ and $\mathrm{A}_{\perp}=-\mathrm{P}\left[\mathrm{k}-2 / 7-11 / 4 \Delta \mathrm{g}_{\perp}\right] . p$-value ranges from 100 to $160 \times 10^{-4} \mathrm{~cm}^{-1}$ in oxidovanadium(IV) compounds [20] and is calculated as $P=g_{e} g_{N} \mu_{B} \mu_{N}\left\langle r^{-3}\right\rangle$, where g is the nuclear $\mathrm{g}$-factor, $\mathrm{g}_{\mathrm{e}}$ is the g-factor of the free electron, $\mu_{\mathrm{N}}$ the nuclear magneton, and $\left\langle\mathrm{r}^{-3}\right\rangle$ can be calculated for the vanadium $3 \mathrm{~d}$ orbitals. The parameter $k$ (between 0.6 to 0.9 ) is the dimensionless Fermi contact interaction constant [21], is very sensitive to deformations of the metal orbitals, and indicates the isotropic Fermi contact contribution to the hyperfine coupling. The calculated value of $P=119.6 \times 10^{-4} \mathrm{~cm}^{-1}$ is considerably reduced when compared to the value of the free ion $\left(160 \times 10^{-4} \mathrm{~cm}^{-1}\right)$ and indicates a considerable amount of covalent bonding in the [ $\mathrm{VO}$ (chrys)phenCl] complex. The value of $k=0.71$ indicates a moderate contribution to the hyperfine constant by the unpaired s-electron. Moreover, the product $P \times k=85.1 \times 10^{-4} \mathrm{~cm}^{-1}$ represents the anomalous contribution of s-electrons to the $\mathrm{A}_{\|}$and $\mathrm{A}_{\perp}$ components (the rest being the contribution of $3 \mathrm{~d}_{\mathrm{xy}}$ electrons) [22].

\subsection{Stability Measurements}

The electronic spectral band for the d-d transition of [ $\mathrm{VO}($ chrys)phenCl] dissolved in DMSO is shifted to blue regarding the precursor complex (VO(chrys) $\left.)_{2}\right)$, in agreement with the changes in the coordination sphere ( $2 \mathrm{O}$ and $2 \mathrm{~N}$ atoms) vs. ( $4 \mathrm{O}$ atoms) (766 nm for [VO(chrys)phenCl] vs. $796 \mathrm{~nm}$ for the binary compound) [5]. The position of the electronic absorption band proved similar to that of $\left[\mathrm{VO}\left(\mathrm{SO}_{4}\right)(\mathrm{phen})_{2}\right]$ in DMSO (ca. $765 \mathrm{~nm}$ ) [23]). Electronic spectra of a DMSO solution of [VO(chrys)phenCl] (t) and conductivity measurements did not show any significant change during $4 \mathrm{~h}$. Figure S2B shows the spectral changes for a solution of the complex in DMSO/ $\mathrm{H}_{2} \mathrm{O} 1 / 99\left(1 \times 10^{-2} \mathrm{M}\right)$, during $4 \mathrm{~h}$. The complex proved less stable in water solutions, but at least during $15 \mathrm{~min}$ (manipulation time for the cellular studies) the complex remained stable in both solutions. It is known that once the complex is added to living cells, it could undergo several chemical interactions with the oxidant and antioxidant cellular systems, including ligand release, but the differences in the anticancer effect between the free ligands and the vanadium complex could demonstrate the efficacy of the vanadium compound.

\subsection{Cytotoxic Assays}

The cytotoxic effect [ $\mathrm{VO}$ (chrys)phenCl] on the human lung cancer cell line A549 was determined by the MTT assay, at 24, 48, and $72 \mathrm{~h}$ incubation (Table 1). The effects were compared with those of the oxidovanadium(IV) cation [16-24], chrysin [25], VO(chyrs) 2 [7], and phen [8], as previously reported.

Table 1. Half maximal inhibitory concentration, $\mathrm{IC}_{50}$, values of $\mathrm{VO}$ (chrys)phenCl and its components (oxidovanadium(IV) cation (VO), chrysin, phen) on A549 cell line at 24, 48 and $72 \mathrm{~h}$ incubation and on HEK cell line for $\mathrm{VO}$ (chrys)phenCl $(24 \mathrm{~h})$. The $\mathrm{IC}_{50}$ values for the binary complex of $\mathrm{VO}$ and chrysin was added for comparisons. The results represent the mean \pm the standard error of the mean (SEM) from three separate experiments.

\begin{tabular}{cccc}
\hline & $\mathrm{IC}_{\mathbf{5 0}}(\boldsymbol{\mu M})$ & $\mathrm{IC}_{\mathbf{5 0}}(\boldsymbol{\mu M})$ & $\mathrm{IC}_{\mathbf{5 0}}(\boldsymbol{\mu M})$ \\
& $\mathbf{2 4} \mathbf{~ h}$ & $\mathbf{4 8 ~ h}$ & $\mathbf{7 2 ~ \mathbf { ~ h }}$ \\
\hline $\mathrm{VO}$ & $>100^{\mathrm{a}}$ & $>100$ & $15 \pm 1.2^{\mathrm{b}}$ \\
chrysin & $>100$ & $66.4 \pm 4.9^{\mathrm{c}}$ & $37.3 \pm 3.5$ \\
Phen d & $66.1 \pm 3.4$ & $23.9 \pm 2.5$ & $1.9 \pm 0.5$ \\
$\mathrm{VO}(\text { chyrs })_{2} \mathrm{e}$ & $>100$ & $41.2 \pm 3.9$ & $6.1 \pm 1.2$ \\
$\mathrm{VO}($ chyrs)phenCl & $28.9 \pm 4.0$ & $8.3 \pm 1.0$ & $1.7 \pm 0.1$ \\
\hline
\end{tabular}

a [16], ${ }^{\mathrm{b}}[24],{ }^{\mathrm{c}}[25],{ }^{\mathrm{d}}[8],{ }^{\mathrm{e}}[7]$. 
The replacement of one chyrsin molecule by phen in the coordination sphere of the binary complex greatly enhanced the anticancer effects at 24 and $48 \mathrm{~h}$ incubation. As can be seen, cell incubation time had an impact on cell viability in a dose-response manner. Higher incubation times $(72 \mathrm{~h})$ result in low $\mathrm{IC}_{50}$ values, and most of the cells that are responding at early times after treatment were lost at the time the assay was performed, owing to the disintegration of cells into particulate debris altering the ratio between the live and dead cell populations present at the time of analysis. Therefore, it is difficult to make cell viability comparisons after $72 \mathrm{~h}$ incubation and this is the reason why the mechanistic studies have been carried out in the present study at $24 \mathrm{~h}$ incubation [26].

It is important to emphasize that the oxidovanadium(IV) complexes may hydrolyze and/or oxidize in aqueous solution. At $24 \mathrm{~h}$ incubation, the $\mathrm{V}^{\mathrm{IV}} \mathrm{O}$ cation showed a high $\mathrm{IC}_{50}$ value without affecting cell viability up to $100 \mu \mathrm{M}$ (Table 1 ), and $\mathrm{V}(\mathrm{V})$ showed a decrease of cell viability of $10-20 \%$ at 50 and $100 \mu \mathrm{M}$ [27]. The anticancer effect of $\mathrm{VO}$ (chyrs)phenCl at $24 \mathrm{~h}$ incubation proved higher than that exerted by the oxidovanadium(IV) cation, its oxidized species, the binary complex, and the ligands. Hence, we are able to discard that the deleterious effect the complex was due to the metal ion, phen, and/or chrysin ligands generated after decomposition processes (or at least we can assume that these processes were slow at $24 \mathrm{~h}$ incubation).

The percentage of non-tumorigenic HEK293 cell viability vs. [VO(chrys)phenCl] concentrations is shown in Figure S3. The complex does not reduce the cellular viability in the range of tested concentrations $(0-100 \mu \mathrm{M})$, indicating that the toxicity of the compound shows a good correlation in terms of selectivity toward A549 cancer cells within $24 \mathrm{~h}$ of tincubation.

\subsection{ROS and GSH/GSSG Cellular Levels}

Cellular oxidative stress is considered to be inducer of carcinogenesis. Cancer cells show high ROS levels and are more vulnerable to ROS. Hence, ROS generating compounds kill cancer cells selectively. Non-transformed cells have a low basal intracellular ROS level and have a full antioxidant capacity, being less vulnerable to the oxidative stress induced by different compounds in cancer cells. To study the role of the oxidative stress in the cytotoxicity induced by the complex, we measured ROS production in A549 cells at $24 \mathrm{~h}$ incubation. From Figure 4, it can be seen that the oxidovanadium(IV) cation did not increase cellular ROS levels, chrysin generated a very low increase of ROS, while phen and the complex elevated the amount of intracellular ROS so that they selectively damage cancer cells. The pro-oxidant nature of the complex and phen improved the anticancer effects of the flavonoid.

Glutathione is an antioxidant, capable to prevent damage produced by ROS in cells, ubiquitously present in all cell types at mM concentration. In mammalian cells under physiological conditions, the GSH redox couple is known to be present with steady-state concentrations of $1-10 \mathrm{mM}$. The overall ratio of GSH to its oxidized state GSSG in a cell is usually greater than 100:1, and the redox couple GSH/GSSG is used as an indicator of changes in the redox environment and of oxidative stress in the cell. In various models of oxidative stress, this ratio has been demonstrated to decrease to values of 10:1 and even 1:1 [28].

The GSH contents in A549 cell line after incubation with the complex were measured (Figure 5A). As GSH depletion is not a major cause of cytotoxicity, the GSH/GSSG was also calculated (Figure 5B) to demonstrate that the decrease of the GSH/GSSG ratio was due not only to a decrease in the level of GSH, but also to an accumulation of GSSG. Therefore, it can be seen that the cellular damage on the A549 cell line is manifested by the increased levels of ROS that exceed the defense mechanisms inducing GSH oxidation with the resultant reduction of cellular GSH. Therefore, a stress oxidative mechanism could be assumed for the cell-killing action of [VO(chrys)phenCl]. 


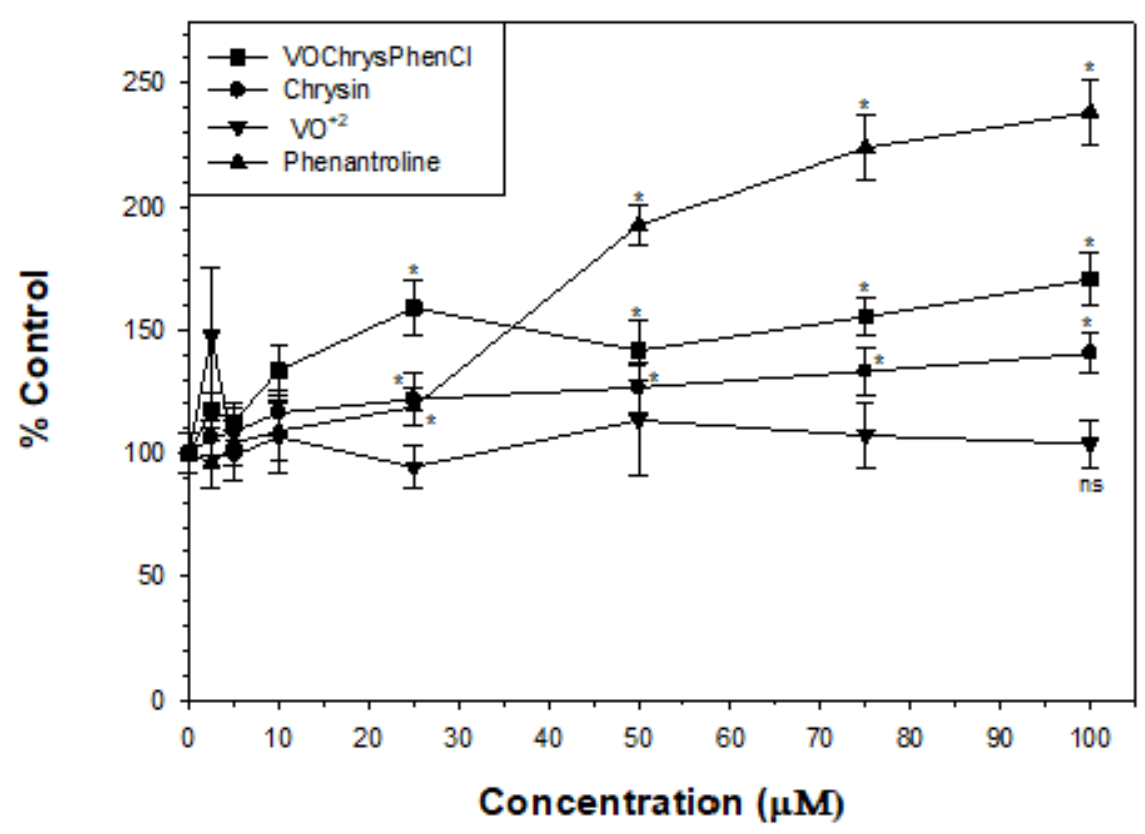

Figure 4. Effect of chrysin, $\mathrm{VO}$ (chrys)phenCl, phen and oxidovanadium(IV) cation on $\mathrm{H}_{2} \mathrm{DCFDA}$ oxidation to DCF. A549 cells were incubated at $37{ }^{\circ} \mathrm{C}$ in the presence of $10 \mu \mathrm{M} \mathrm{H} \mathrm{H}_{2} \mathrm{DCFDA}$. The values are expressed as the percentage of the control level and represent the mean \pm SEM. ${ }^{*} p<0.05$, ns: not significant.

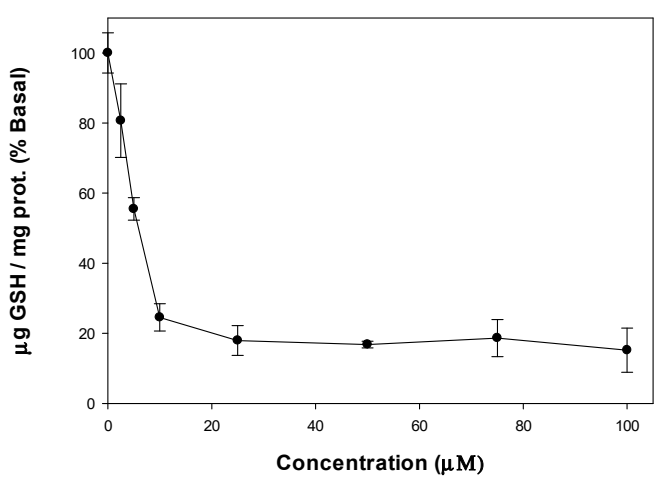

(A)

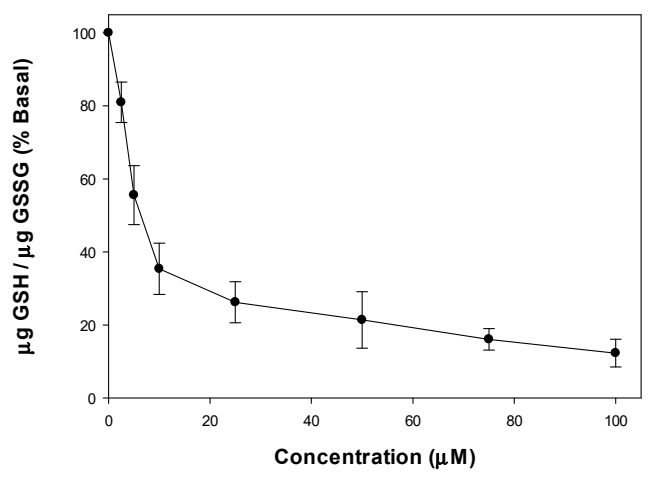

(B)

Figure 5. Effect of [VO(chrys)phenCl] on GSH cellular levels (A) and GSH/GSSG ratio (B) in A549 cells, $24 \mathrm{~h}$ incubation. Results are expressed as mean \pm SEM of three independent experiments. All values are statistically significant in comparison with the control.

\subsection{Mitochondrial Membrane Potential}

The loss of mitochondrial function and the subsequent release of cytochrome $\mathrm{C}$ into the intracellular space are some of the mechanisms associated with the apoptosis process [29]. The mitochondrial membrane potential $(\Delta \psi)$ was measured to explain the increase of cellular ROS and decrease of the GSH/GSSG ratio on the A549 cell line by incubation of the metal complex. The lipophilic cationic probe DioC6 enters the mitochondria and upon depolarization it will accumulate less dye [30]. Figure 6 shows the effect of mitochondrial dysfunction with a membrane potential loss when A549 cells were treated with increasing concentrations of the metal complex in concordance with a stress oxidative mechanism. 


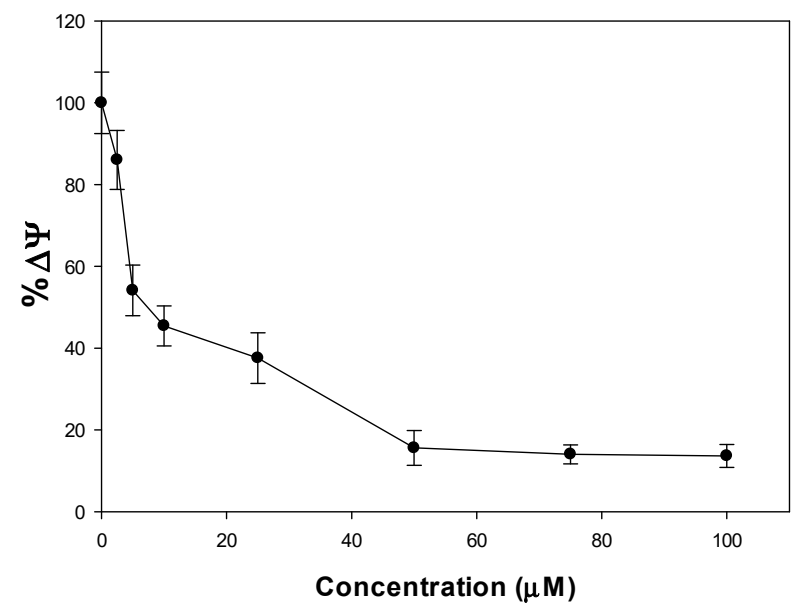

Figure 6. Changes of the mitochondrial membrane potential $(\% \Delta \psi)$ in A549 cells treated with increasing concentrations of $\mathrm{VO}$ (chrys)phenCl for $24 \mathrm{~h}$. Each point represents the mean \pm S.E.M of three measurements in three independent experiments. All values are statistically significant in comparison with the control.

\subsection{Cellular Vanadium Uptake Experiments}

The vanadium content after $24 \mathrm{~h}$ treatment of the compounds at a concentration equivalent to [VO(chrys)phenCl] $\mathrm{IC}_{50}(28.9 \mu \mathrm{M})$ was determined by inductively coupled plasma-mass-spectrometry, ICP-MS (see Table 2). VO(acac) $)_{2}$ exhibited almost the same capacity for cellular uptake as the control. Our results are comparable with data reported for the human A2780 ovarian cancer cells [31]. For [VO(chrys)phenCl], the total amount of $\mathrm{V}$ up-taken is ca. five-fold higher than for the binary complex. Our data suggest that its greatest cytotoxicity might be directly correlated with the incorporation of phen into the complex structure, increasing its lipophilicity, which could improve the cellular uptake.

Table 2. Cellular V content (determined by ICP-MS) following cell treatments with $28.9 \mu \mathrm{M}$ of compounds for $24 \mathrm{~h}$. Results are expressed as mean \pm the standard error of the mean (SEM) of two independent experiments.

\begin{tabular}{cc}
\hline & Nmol V/Mg Protein \\
\hline Control & $4.6 \pm 0.5$ \\
$\mathrm{VO}(\text { acac })_{2}$ & $4.9 \pm 0.2$ \\
$\mathrm{VO}($ chrys) & 2 \\
{$[\mathrm{VO}($ chrys)phenCl $]$} & $4.7 \pm 0.1$ \\
\hline
\end{tabular}

\subsection{BSA (Bovine Serum Albumin) Interactions}

The binding behavior of drugs with albumin affected their distribution and metabolism in the body. Both human serum albumin (HSA) and BSA are commonly used to determine the binding interactions because they possess near $76 \%$ sequence homology and tertiary structure similarity [32]. To study the protein binding ability of the complex, we have selected BSA herein because of its low cost and wide availability. The intrinsic fluorescence of BSA is due to tryptophan residue when excited at $295 \mathrm{~nm}$. Upon titration of BSA with increasing concentrations of the complex, the fluorescence spectra showed a decrease in the intensity or quenching (Figure S4). The Stern-Volmer quenching constant was obtained from the slope of the graph of the fluorescence intensities $\mathrm{F}_{0} / \mathrm{F}$ (in the absence and presence of the quencher, respectively, and corrected by the inner-filter effect) vs. the quencher concentration, $\mathrm{Q}$, according to the equation: $\mathrm{F}_{0} / \mathrm{F}=1+\mathrm{K}_{\mathrm{q}} \tau_{0}[\mathrm{Q}]=1+\mathrm{K}_{\mathrm{SV}}[\mathrm{Q}]$, where $\mathrm{K}_{\mathrm{q}}$ is the bimolecular quenching constant and $\tau_{0}$ is the lifetime of the fluorophore in the absence of the quencher (considered $1 \times 10^{-8} \mathrm{~s}$ for a biopolymer) [33]. 
An upward curvature of the plots at different temperatures can be seen, showing a combined quenching (static and dynamic). However, at low concentrations, a linear correlation was obtained (Figure 7). The linearity at lower concentrations suggested a single quenching type. Static and dynamic quenching can be differentiated by the analysis of the temperature dependence. Using the data of the linear region, $\mathrm{K}_{\mathrm{sv}}$ and $\mathrm{K}_{\mathrm{q}}$ $\left(\mathrm{K}_{\mathrm{q}}=\mathrm{K}_{\mathrm{sv}} / \tau_{0}, \tau_{0}=10^{-8} \mathrm{~s}\right)$ were calculated (Table 3). The Ksv values showed a decrease with increasing temperature, suggesting a static quenching mechanism. Another criterion for the type of static cooling is that the result of the bimolecular cooling constant should be greater than the maximum dynamic cooling constant for a biopolymer, assumed to be $2.0 \times 10^{10} \mathrm{M}^{-1} \mathrm{~s}^{-1}$. As can be seen in Table 3, all the values of $\mathrm{K}_{\mathrm{q}}$ obtained were greater than that value, reinforcing the assumption that a static quenching type of interaction between the complex and albumin takes place.

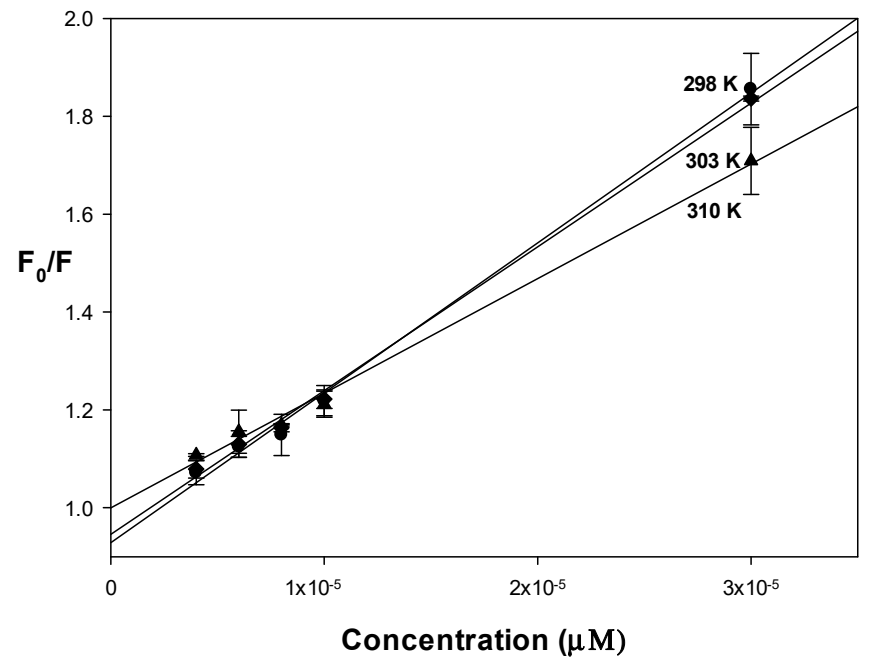

Figure 7. Stern Volmer graph for $\mathrm{VO}$ (chrys)phenCl at different temperatures, [BSA] $=6 \mu \mathrm{M}$, $\lambda_{\mathrm{ex}}=280 \mathrm{~nm}$.

Table 3. Stern-Volmer constant $\left(\mathrm{K}_{\mathrm{sv}}\right)$, bimolecular quenching constant $\left(\mathrm{K}_{\mathrm{q}}\right)$, binding constant $\left(\mathrm{K}_{\mathrm{b}}\right)$ and number of binding sites $(\mathrm{n})$ for the interaction of $\mathrm{VO}($ chrys)phenCl with BSA $(6 \mu \mathrm{M})$ in Tris-HCl buffer (0.1 M, pH 7.4).

\begin{tabular}{cccccc}
\hline $\mathbf{T}(\mathbf{K})$ & $\begin{array}{c}\mathbf{K}_{\text {sv }}\left(\times \mathbf{1 0}^{\mathbf{4}}\right) \\
\left(\mathbf{M}^{-\mathbf{1})}\right.\end{array}$ & $\mathbf{r}^{\mathbf{2}}$ & $\begin{array}{c}\mathbf{K}_{\mathbf{q}}\left(\times \mathbf{1 0}^{\mathbf{1 2}}\right) \\
\left.\mathbf{M}^{-\mathbf{1}} \mathbf{s}^{-\mathbf{1}}\right)\end{array}$ & $\begin{array}{c}\mathbf{K}_{\mathbf{b}}\left(\times \mathbf{1 0}^{\mathbf{5}}\right) \\
\left(\mathbf{M}^{-\mathbf{1}}\right)\end{array}$ & $\mathbf{n}$ \\
\hline 298 & $3.06 \pm 0.11$ & 0.98 & $3.06 \pm 0.11$ & $3.16 \pm 0.24$ & $1.24 \pm 0.07$ \\
303 & $2.94 \pm 0.07$ & 0.99 & $2.94 \pm 0.07$ & $1.58 \pm 0.34$ & $1.17 \pm 0.06$ \\
310 & $2.34 \pm 0.10$ & 0.97 & $2.34 \pm 0.10$ & $0.16 \pm 0.11$ & $0.96 \pm 0.06$ \\
\hline
\end{tabular}

To determine the binding constant $\left(\mathrm{K}_{\mathrm{b}}\right)$ and the number of binding sites $\mathrm{n}$ (Table 3 ), the Scatchard equation $\left(\log \left[\left(\mathrm{F}_{0}-\mathrm{F}\right) / \mathrm{F}\right]=\log \mathrm{K}_{\mathrm{b}}+\mathrm{n} \log [\mathrm{Q}]\right)$ was used (Figure 8). Binding constants prove to be in the order of $10^{5}-10^{6} \mathrm{M}^{-1}$ and decrease at higher temperature, indicating a reduction in stability of the BSA-complex compound, and confirming the involvement of a static quenching. However, the obtained values suggest that the interactions are adequate for the complex to be transported and delivered by BSA. The number of binding sites ( $c a .1$ ) indicated that the complex may occupy one binding site of the protein. 


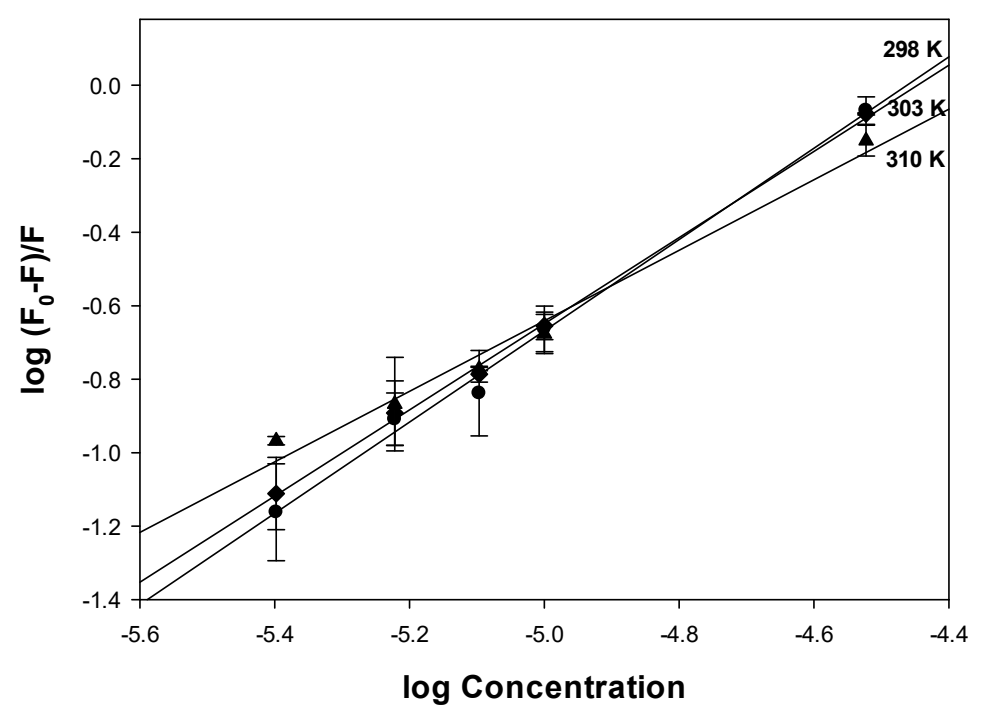

Figure 8. Plots of $\log \left[\left(\mathrm{F}_{0}-\mathrm{F}\right) / \mathrm{F}\right]$ vs. $\log [\mathrm{Q}]$ for the VO(chrys)phenCl-BSA system at $298 \mathrm{~K}, 303 \mathrm{~K}$ and $310 \mathrm{~K},[\mathrm{BSA}]=6 \mu \mathrm{M}, \lambda_{\mathrm{ex}}=280 \mathrm{~nm}$.

To determine the main forces operating during the protein binding, thermodynamic parameters were determined, using the van't Hoff equation $\ln \mathrm{K}_{\mathrm{a}}=-\Delta \mathrm{H} / \mathrm{RT}+\Delta \mathrm{S} / \mathrm{R}$ and $\Delta \mathrm{G}=\Delta \mathrm{H}-\mathrm{T} \Delta \mathrm{S}$ (Table 4). From the negative values of $\Delta \mathrm{G}$, a spontaneous interaction can be confirmed and the decrease of $\Delta \mathrm{G}$ at higher temperatures indicated a decrease of the binding strength of the complex-protein bond. The negative values of enthalpy and entropy changes indicate that hydrogen bond and van der Waals forces were the major forces operating during the interaction [34].

Table 4. Thermodynamic parameters for the interactions between [VO(chrys)phenCl] with BSA.

\begin{tabular}{ccc}
\hline$\Delta \mathbf{H}(\mathrm{KJ} / \mathbf{M o l})$ & $\Delta \mathbf{S}(\mathrm{J} / \mathbf{M o l})$ & $\Delta \mathrm{G}(\mathrm{KJ} / \mathrm{Mol})$ \\
\hline & & $-32.2(298 \mathrm{~K})$ \\
-207.8 & -588.9 & $-29.3(303 \mathrm{~K})$ \\
& & $-25.1(310 \mathrm{~K})$ \\
\hline
\end{tabular}

\section{Discussion}

To enhance the biological action of $\mathrm{VO}$ (chrys) $)_{2}$ complex, one chrysin ligand was replaced by the planar ligand phen in the metal coordination sphere and the new complex was characterized by common analytical techniques. FTIR studies indicated that the oxidovanadium(IV) ion interacted with $\mathrm{C}=\mathrm{O}$ and $\mathrm{O}^{-}$atoms of chrysin and $\mathrm{N}$ atoms of phen. Conductivity studies indicated that the chloride ion, which contributed to the electroneutrality of the complex, is also bonded to the $\mathrm{V}=\mathrm{O}$ moiety, in trans- position (solution EPR determinations). Conductivity and spectral determinations in DMSO and $\mathrm{DMSO} / \mathrm{H}_{2} \mathrm{O}$ showed that the complex did not produce hydrolytic species during the manipulation time of the complex. It has to be noted that the cellular experiments consist in the addition to the cells of a fresh DMSO stock solution of the complex dissolved in the culture media (with a final DMSO concentration of $0.5 \%$ ) and, therefore, the studies of the stability of the complex must be performed not only on DMSO and the culture media, but the cell components must also be considered (including natural antioxidant compounds that must also been taken under consideration in those kind of studies), as previously mentioned [35]. However, the determination of the speciation in aqueous solution of the complex inside the cell is outside the scope of this study.

In a previous paper, the cytotoxicity of $c i s-\left[\mathrm{V}^{\mathrm{IV}} \mathrm{O}\left(\mathrm{OSO}_{3}\right)(\text { phen })_{2}\right]$ at $72 \mathrm{~h}$ incubation in the A549 cell line was related to its decomposition in cell culture medium generating the ligands and the oxidation of vanadium [36]. Another study showed that up to $24 \mathrm{~h}$ 
incubation of the same compound on different ovarian cancer cell lines displayed different $\mathrm{IC}_{50}$ values than the free ligands and inorganic $\mathrm{V}(\mathrm{IV})$ and $\mathrm{V}(\mathrm{V})$ ions, determining that the biological effects were due to the complex, which is more active than the free ligands [23]. However, at $72 \mathrm{~h}$ incubation, similar $\mathrm{IC}_{50}$ values were obtained, probably due to chemical changes of the metal complex.

From the data in Table 1, we are able to discard that the cytotoxic effect was due to phen and/or chrys ligands, generated after decomposition processes at least at $24 \mathrm{~h}$ incubation, because there were no deleterious effects of the binary complex and chrysin, while the $\mathrm{IC}_{50}$ value measured for phen was $66 \mu \mathrm{M}$, corresponding to more than twice the $\mathrm{IC}_{50}$ value of the complex. Besides, we measured the effect of the $24 \mathrm{~h}$ cell incubation with the mixture of each component of the complex in stoichiometric quantities (sodium metavanadate, chrysin and phen, physiological $\mathrm{pH}$ ). It produced the same inhibitory effect from 10 to $50 \mu \mathrm{M}$ ( $c a .50 \%$ viable cells, Figure S5) and, hence, the $\mathrm{IC}_{50}$ value could not be determined. However, we can conclude that the effect of the mixture proved different from that of the complex (that inhibited cell viability in a dose dependent manner), discarding that the cytotoxic activity of the complex was due to decomposition followed by oxidovanadium(IV) oxidation in the culture media.

It is well known that ROS overproduction is the cause of the development of a number of diseases. Excessive ROS accumulation and the depletion of natural antioxidant compounds such as GSH can cause irreversible cell damage and even cell death [37]. We determined herein that one mechanism involved in the process of cell death is the induction of oxidative stress by the metal complex accompanied by disruption of the mitochondria membrane potential. Meanwhile, the loss of mitochondrial membrane potential is related to activation of the mitochondrial apoptosis pathways. The presence of the lipophilic ligand, phen, favors the cellular uptake of the metal. Phen coordinates to oxidovanadium(IV) cation, improving its transport inside cells, hence behaving as a better cytotoxic agent via the induction of oxidative stress and mitochondrial membrane damage than the $\mathrm{VO}$ (chrys) $)_{2}$ complex.

The replacement of one chrys ligand by phen in VOchrysphenCl produced a tighter interaction to BSA than $\mathrm{VO}(\text { chrys })_{2}\left(\mathrm{~K}_{\mathrm{b}} 0.76 \times 10^{5} \mathrm{M}^{-1}\right)$ [7]. Both compounds bind to BSA in a spontaneous and enthalpy-driven manner and could be transported by albumin $\left(\mathrm{K}_{\mathrm{b}}\right.$ values in the range of $\left.10^{4}-10^{6} \mathrm{M}^{-1}\right)$.

\section{Materials and Methods}

\subsection{Materials and Instrumentation}

Chrysin (Sigma, Buenos Aires, Argentina), phenanthroline hydrochloride (Merck, Buenos Aires, Argentina), and vanadyl acetylacetonate (Fluka Munich, Germany) were used as supplied. Corning or Falcon provided tissue culture materials. Dulbecco's modified Eagle's medium (DMEM, Gibco, Gaithersburg, MD, USA), Tryple ${ }^{\mathrm{TM}}$ (Invitrogen, Buenos Aires, Argentina) and fetal bovine serum (FBS, Internegocios, Buenos Aires, Argentina) were used as provided. All other chemicals used were of analytical grade. Elemental analysis for carbon, nitrogen, and hydrogen was performed using a Carlo Erba EA1108 analyzer. Vanadium content was determined by the tungstophosphovanadic method [38]. Thermogravimetric analysis was performed with Shimadzu systems (model TG-50), working in an oxygen flow of $50 \mathrm{~mL} \cdot \mathrm{min}^{-1}$ and at a heating rate of $10^{\circ} \mathrm{C} \cdot \mathrm{min}^{-1}$. Sample quantities ranged between 10 and $20 \mathrm{mg}$. UV-vis and diffuse reflectance spectra were recorded on a Hewlett-Packard 8453 diode-array and a Shimadzu 2600/2700 spectrophotometer. Infrared spectra were measured with a Bruker IFS 66 FTIR spectrophotometer from 4000 to $400 \mathrm{~cm}^{-1}$ using the $\mathrm{KBr}$ pellet technique. Fluorescence spectra were obtained with a Shimadzu RF-6000 spectrophotometer equipped with a pulsed xenon lamp. The molar conductance of the complex was measured on a Conductivity TDS Probe-850084, Sper Scientific Direct, using $10^{-3} \mathrm{M}$ DMSO solutions. Exact mass spectra were obtained using a Bruker micrOTOF-Q II mass spectrometer, equipped with an ESI source operating in positive mode. 
A Bruker EMX-Plus spectrometer, equipped with a rectangular cavity with $100 \mathrm{kHz}$ field modulation and with standard Oxford Instruments low-temperature devices (ESR900/ITC4), was used to record the EPR spectra of both powdered and DMSO solution spectra. The spectra, obtained at $100 \mathrm{~K}$ to room temperature ( $c a .298 \mathrm{~K}$ ) were, when necessary, baseline corrected using WinEPR Processing software (Bruker, Inc., Billerica, MA, USA).

The EasySpin 5.2.3. toolbox based on MATLAB was used to simulate g- and A- values [39], assuming an axial spin-Hamiltonian of the form:

$$
H=\mu_{B}\left[g_{\|} B_{z} S_{z}+g_{\perp}\left(B_{x} S_{x}+B_{y} S_{y}\right)\right]+\left[A_{\|} S_{z} I_{z}+A_{\perp}\left(S_{x} I_{x}+S_{y} I_{y}\right)\right]
$$

where $\mu_{B}$ is the Bohr magneton, and $g_{\|}, g_{\perp}, A_{\|}, A_{\perp}$ are the components of the axial $\mathbf{g}$ and A tensors, respectively. $B_{x / y / z}, S_{x / y / z}$, and $I_{x / y / z}$ are the components of the magnetic field, and of the spin operators of the electron and V nucleus, respectively.

\subsection{Preparative [VO(chrys)phenCl]}

The binary complex $\left[\mathrm{VO}(\text { chrys })_{2} \mathrm{EtOH}\right]_{2}(0.1 \mathrm{mmol})$ prepared as in [5] and phenanthroline hydrochloride $(0.2 \mathrm{mmol})$ in acetone $(25 \mathrm{~mL})$ were poured into a round bottomed flask and refluxed for $3 \mathrm{~h}$. The precipitate was filtered and washed three times with hot acetone. The green-yellow solid was dried in an oven at $60{ }^{\circ} \mathrm{C}$. Anal calc for $\mathrm{C}_{27} \mathrm{H}_{17} \mathrm{ClN}_{2} \mathrm{O}_{5} \mathrm{~V}$ : $535.9 \mathrm{~g} / \mathrm{mol}$; C, 60.5; H, 3.2; N, 5.2; V, 9.5\%. Exp, C, 60.4; H, 3.3; N, 5.3; V, 9.6. Diffuse reflectance spectrum: $201 \mathrm{~nm}, 208 \mathrm{~nm}, 226 \mathrm{~nm}, 276 \mathrm{~nm}, 333 \mathrm{~nm}(\mathrm{sh}), 396 \mathrm{~nm}, 782 \mathrm{~nm}$. UV-Vis (DMSO): $273 \mathrm{~nm}\left(105,300 \mathrm{M}^{-1} \mathrm{~cm}^{-1}\right) 288 \mathrm{~nm}\left(91,100 \mathrm{M}^{-1} \mathrm{~cm}^{-1}\right) 326 \mathrm{~nm}\left(12,341 \mathrm{M}^{-1} \mathrm{~cm}^{-1}\right)$ $392 \mathrm{~nm}\left(6143 \mathrm{M}^{-1} \mathrm{~cm}^{-1}\right) 769 \mathrm{~nm}\left(68 \mathrm{M}^{-1} \mathrm{~cm}^{-1}\right)$. Electrospray ionization mass spectrometry (ESI-MS) analyses for the complex dissolved in DMSO:acetone (1:2): ESI-MS(+) (m/z) (calc for $\mathrm{C}_{27} \mathrm{H}_{17} \mathrm{ClN}_{2} \mathrm{NaO}_{5} \mathrm{~V}$ ): 558.02 [M - Na] ${ }^{+}$, (found): 558.01, for $\mathrm{M}$, [VO(chrys)phenCl] and $[\mathrm{M}-\mathrm{Na}]^{+},\left[\mathrm{VO}(\text { chrys)phenCl }-\mathrm{Na}]^{+}\right.$. The mass-to-charge ratio peak detected at $(\mathrm{m} / \mathrm{z})$ $500.05(100 \%)$ was due to the presence of [VOchrysphen] ${ }^{+}$species: the ligand chloride dissociates under the ESI-MS conditions and the bidentate ligands remained bonded to the metal ion (chelate effect, higher stability), as shown in Figure S6.

\subsection{Cell Viability Assay (MTT Assay)}

Cell viability was measured by the 3-[4,5-dimethylthylthiazol-2-yl]-2,5 diphenyltetrazolium bromide (MTT) (Sigma-Aldrich, St. Louis, MO, USA) method. Briefly, A549 cells (human lung cancer cell line) and HEK293 (human embryonic kidney) were maintained at $37^{\circ} \mathrm{C}$ in a $5 \%$ carbon dioxide atmosphere using DMEM supplemented with $100 \mathrm{U} / \mathrm{mL}$ penicillin, $100 \mu \mathrm{g} / \mathrm{mL}$ streptomycin, and 10\% (v/v) fetal bovine serum as the culture medium. When 70-80\% confluence was reached, cells were subcultured using TrypLE TM and free phosphate buffered saline (PBS) $\left(11 \mathrm{mM} \mathrm{KH}_{2} \mathrm{PO}_{4}, 26 \mathrm{mM} \mathrm{Na}_{2} \mathrm{HPO}_{4}, 115 \mathrm{mM} \mathrm{NaCl}\right.$, $\mathrm{pH}$ 7.4). For the treatments, cells were seeded at a density of $1 \times 10^{5}$ per well in 48 well plates, grown overnight, then incubated with the complex, metal ion, and ligands in FBS free medium. After different incubation times, at $37^{\circ} \mathrm{C}, 100 \mu \mathrm{g}$ of MTT per well were added and incubated was performed in a $\mathrm{CO}_{2}$ incubator for $2 \mathrm{~h}$ at $37^{\circ} \mathrm{C}$. DMSO was then added to dissolve formazan crystals and the absorbance of each well was measured by a plate reader at a test wavelength of $560 \mathrm{~nm}$. Data are presented as the percentage of cell viability $(\%)$ of the treated group with respect to the untreated cells (control), whose viability is assumed to be $100 \%$.

\subsection{Oxidative Stress Determinations}

Reactive oxygen species (ROS) generation in A549 cell lines was measured by oxidation of $2^{\prime}, 7^{\prime}$-dichlorodihydrofluorescein diacetate ( $\left.\mathrm{H}_{2} \mathrm{DCFDA}\right)$ to $2^{\prime}, 7^{\prime}$-dichlorofluorescein (DCF). Briefly, 24-well plates were seeded with $5 \times 10^{4}$ cells per well and allowed to adhere overnight. Then, different concentrations of the compounds were added. After $24 \mathrm{~h}$ incubation, media was removed, and cells were loaded with $10 \mu \mathrm{M} \mathrm{H}_{2}$ DCFDA diluted in clear media for $30 \mathrm{~min}$ at $37^{\circ} \mathrm{C}$. Media was then separated and the cell monolayers rinsed 
with PBS and lysated into $1 \mathrm{~mL} 0.1 \%$ Triton-X100. The oxidized product DCF was analyzed in the cell extracts using fluorescence spectroscopy $\left(\lambda_{\mathrm{ex}}, 485 \mathrm{~nm} ; \lambda_{\mathrm{em}}, 535 \mathrm{~nm}\right)$ [40].

Natural antioxidant levels of glutathione (GSH) and its oxidized product (GSSG) were determined in A549 cell lines in culture. Confluent cell monolayers from 24 well dishes were incubated with different concentrations of the compounds at $37^{\circ} \mathrm{C}$ for $24 \mathrm{~h}$. Then, the monolayers were washed with PBS and harvested by incubating them with $300 \mu \mathrm{L}$ Triton $0.1 \%$ for $30 \mathrm{~min}$. For GSH determinations, $100 \mu \mathrm{L}$ aliquots were mixed with $1.8 \mathrm{~mL}$ of ice cold phosphate buffer $\left(\mathrm{Na}_{2} \mathrm{HPO}_{4} 0.1 \mathrm{M}\right.$-EDTA $\left.0.005 \mathrm{M}, \mathrm{pH} 8\right)$ and $100 \mu \mathrm{L}$ o-phthaldialdehyde (OPT) $(0.1 \%$ in methanol) [41]. For the determination of GSSG, the cellular extracts were incubated with $0.04 \mathrm{M}$ of N-ethylmaleimide (NEM) to avoid GSH oxidation, $100 \mu \mathrm{L}$ aliquots were mixed with $1.8 \mathrm{~mL} \mathrm{NaOH} 0.1 \mathrm{M}$ and OPT, and the fluorescence was determined $\left(\lambda_{\mathrm{ex}}, 350 \mathrm{~nm} ; \lambda_{\mathrm{em}}, 420 \mathrm{~nm}\right)$. Standard curves with different concentrations of GSH were processed in parallel. The protein content in each cellular extract was quantified using the Bradford assay [42]. The better marker for the cellular redox status, the GSH/GSSG ratio, was calculated as \% control for all the experimental conditions.

The mitochondrial membrane potential was assessed to evaluate the mitochondrial function, using the $\mathrm{DiOC}_{6}$ (3,3'-Dihexyloxacarbocyanine Iodide) fluorescent probe. The probe was added to the wells ( $400 \mathrm{nM}$ concentration) and incubated for $30 \mathrm{~min}$ at $37^{\circ} \mathrm{C}$. The cells were resuspended in PBS and measured using fluorescence spectroscopy $\left(\lambda_{\mathrm{ex}}\right.$, $\left.485 \mathrm{~nm} ; \lambda_{\mathrm{em}}, 535 \mathrm{~nm}\right)$ [43].

\subsection{Cellular Vanadium Uptake Experiments}

For vanadium uptake experiments, cells were grown to $80 \%$ confluence in $100 \mathrm{~mm}$ petri dishes. Incubations with the treatment compounds $(28.9 \mu \mathrm{M}$ of $\mathrm{VO}$ (chyrs)phenCl, $\mathrm{VO}$ (chrys $)_{2}$ and $\mathrm{VO}(\text { acac })_{2}$ in $0.5 \% \mathrm{DMSO}$ ) were performed for $24 \mathrm{~h}$. Afterwards, $\mathrm{V}$ containing media were removed, and the cell layers were washed twice with PBS. Cells were detached using TrypLE enzyme solution for ca. $15 \mathrm{~min}$ at $37^{\circ} \mathrm{C}$. The cell suspensions were collected into centrifuge tubes and pelleted at $4000 \times g$ for $2 \mathrm{~min}$. The cell pellets were washed once with phosphate buffered saline $(1.0 \mathrm{~mL}$ per tube) and lysed with $100 \mu \mathrm{L} 0.10 \mathrm{M}$ $\mathrm{NaOH}$ overnight at $4{ }^{\circ} \mathrm{C}$. Each lysate $(2 \mu \mathrm{L})$ was mixed with $98 \mu \mathrm{L}$ of Bradford reagent and the absorbance at $560 \mathrm{~nm}$ was measured using a plate reader for the determination of protein content. Freshly prepared solutions $\left(0-2.0 \mathrm{mg} \mathrm{mL}^{-1}\right.$ in $\left.0.10 \mathrm{M} \mathrm{NaOH}\right)$ of bovine serum albumin were used for calibration. The rest of the lysate was diluted to $1.0 \mathrm{~mL}$ with $20 \% \mathrm{HNO}_{3}$ and vanadium contents in the resultant solutions were determined by ICP-MS. Corresponding amounts of $\mathrm{NaOH}$ and $\mathrm{HNO}_{3}$ solutions were used to prepare the blank samples. The content of vanadium in the cell lysates was calculated in nmol $V$ per $\mathrm{mg}$ protein [44].

\subsection{BSA Interactions}

The fluorescent technique was used for the measurement of the interactions with BSA. BSA in Tris- $\mathrm{HCl}(0.1 \mathrm{M}, \mathrm{pH}=7)$ was kept constant at $6 \mu \mathrm{M}$ and titrated with different concentrations of the complex ranging from 2 to $30 \mu \mathrm{M}$ with an incubation time of $1 \mathrm{~h}$. For the experiments, the quenching of the emission intensity of BSA (at $336 \mathrm{~nm}$ ) by the complex was monitored at $\lambda_{\mathrm{ex}}=280 \mathrm{~nm}$ with excitation and emission slits of $10 \mathrm{~nm}$. Three different temperatures were selected for thermodynamic determinations $(298,303$, and $310 \mathrm{~K})$. Because of the absorption of the BSA-complex near the excitation wavelength, the fluorescence intensities were corrected by the inner-filter effect, using: $\left.F_{c o r r}=F_{o b s} \times e^{(1 / 2 \mathrm{~A}} e^{+1 / 2} A_{e m}\right)$, where $\mathrm{F}_{\text {corr }}$ and $\mathrm{F}_{\mathrm{obs}}$ are the fluorescence intensities corrected by inner-filter effect and recorded, respectively, $A_{e x}$ and $A_{e m}$ are the electronic absorbances of the solutions at excitation and emission wavelengths, respectively [33]. Three independent replicates were performed for each sample and concentration. 


\subsection{Statistical Analysis}

Statistical differences were analyzed using the analysis of variance method (ANOVA) followed by the test of least significant difference (Fisher). Statistical significance was defined as $p<0.05$.

\section{Conclusions}

A new oxidovanadium(IV) metal complex with the flavonoid chrysin and phen has been synthesized and characterized. In vitro cytotoxicity testing showed that the compound exhibit significant cytotoxicity towards A549 cell line at different incubation times, indicating that the compound has the potential to act as an effective metal-based anticancer drug. The induction of intracellular reactive oxygen species (ROS) production, perturbation of mitochondrial membrane potential, and GSH and GSH/GSSG depletion suggested the ability of the complex to induce cell death by the initiation or progression of oxidative stress. It can be seen that while the complexation of the natural antioxidant chrysin by the oxidovanadium(IV) cation increased the anticancer effect of the flavonoid, the addition of phen in the coordination sphere produced a higher cytotoxic effect and a better vanadium cellular uptake. In this sense, we can discard a total decomposition of the complex leading to the release of the free ligands (being only one of them (phen) biologically active but with low cytotoxicity) at $24 \mathrm{~h}$ incubation. In addition, the metal complex did not show toxic effects against a non-tumorigenic cell line and could be stored and transported by albumin.

Supplementary Materials: The following are available online at https:/ / www.mdpi.com/article / 10.3390/inorganics10010004/s1, Figure S1. EPR spectrum of [VO(chrys)phenCl]. (A) Powder sample at $120 \mathrm{~K}$ (black) and $298 \mathrm{~K}$ (red). (B) Frozen DMSO solution EPR spectrum recorded at $120 \mathrm{~K}$ (black) together with simulation (red). EPR spectra of both powder and DMSO solution were recorded in a Bruker EMX-Plus spectrometer, equipped with a rectangular cavity. Experimental conditions: $100 \mathrm{kHz}$ modulation field, $4 \mathrm{Gpp}$ modulation amplitude and $2 \mathrm{~mW}$ microwave power. The spectra were baseline corrected using WinEPR Processing software (Bruker, Inc.) and simulations were performed with the Easy Spin 5.2.3. toolbox based on MATLAB assuming an axial spin-Hamiltonian. The spin Hamiltonian parameters obtained were $\mathrm{g}_{\mathrm{II}}=1.941 ; \mathrm{A}_{\mathrm{II}}=162.2 \times 10^{-4} \mathrm{~cm}^{-1} ; \mathrm{g}_{\perp}=1.977$; $\mathrm{A}_{\perp}=59.5 \times 10^{-4} \mathrm{~cm}^{-1}$. Figure S2. Spectral variation of a dissolution of [VO(chrys)phenCl] in (A) DMSO, (B) DMSO $/ \mathrm{H}_{2} \mathrm{O} 1 / 99\left(1 \times 10^{-2} \mathrm{M}\right)$, during $4 \mathrm{~h}$. Figure S3. Cell viability assay at different of [ $\mathrm{VO}$ (chrys)phenCl] concentrations after treatment for $24 \mathrm{~h}$ on HEK293 cells. The results are expressed as a percentage of the control level and represent the mean \pm the standard error of the mean (SEM) from three separate experiments. * indicates significant values in comparison with the control level $(p<0.05)$. Figure S4. The fluorescence spectra of BSA at various temperatures for VOchrysphen $(0,4,6,8,10,30 \mu \mathrm{M}) . \lambda \mathrm{ex}=280 \mathrm{~nm}$, [BSA] $=6 \mu \mathrm{M}$. Figure S5. Cell viability assay of a mixture of sodium metavanadate, chrysin and phen (1:1:1), physiological pH at different concentrations after treatment for $24 \mathrm{~h}$ on A549 cells. The results are expressed as a percentage of the control level and represent the mean \pm the standard error of the mean (SEM) from three separate experiments. * indicates significant values in comparison with the control level $(p<0.05)$. Figure S6. Electrospray ionization-mass spectrometry (ESI-MS) spectrum of [VO(chrys)phenCl].

Author Contributions: Conceptualization, P.A.M.W.; validation, E.G.F., L.G.N. and P.A.M.W.; formal analysis, A.A.D. and L.G.N.; investigation, A.A.D.; measurements, P.J.G. and M.R.; resources, P.A.M.W.; writing —original draft preparation, A.A.D., E.G.F. and P.J.G.; writing-review and editing, P.A.M.W.; visualization, P.A.M.W.; supervision, P.A.M.W. and L.G.N.; project administration, P.A.M.W.; funding acquisition, P.A.M.W. All authors have read and agreed to the published version of the manuscript.

Funding: This research was funded by ANPCyT, 2019-0945 and UNLP X871.

Institutional Review Board Statement: Not applicable.

Informed Consent Statement: Not applicable.

Data Availability Statement: The data presented in this study are available in the Supplementary Materials. 


\begin{abstract}
Acknowledgments: This work was supported by UNLP (X871), CICPBA, and ANPCyT (PICT 20180985), Argentina. LGN and EGF are members of the Research Career, CONICET, Argentina. PAMW is member of the Research Career, CICPBA. AAD is fellowship holder from CONICET.

Conflicts of Interest: The authors declare no conflict of interest. The funders had no role in the design of the study; in the collection, analyses, or interpretation of data; in the writing of the manuscript, or in the decision to publish the results.
\end{abstract}

\title{
References
}

1. Stompor-Goracy, M.; Bajek-Bil, A.; Machaczka, M. Chrysin: Perspectives on Contemporary Status and Future Possibilities as Pro-Health Agent. Nutrients 2021, 13, 2038. [CrossRef]

2. Crans, D.C.; Henry, L.R.; Cardiff, G.; Posner, B.I. Developing vanadium as an antidiabetic or anticancer drug: A clinical and historical perspective. In Essential Metals in Medicine: Therapeutic Use and Toxicity of Metal Ions in the Clinic; Peggy, L., Carver, Eds.; De Gruyter: Berlin, Germany, 2019; pp. 203-230. [CrossRef]

3. Siegel, R.L.; Miller, K.D.; Jemal, A. Cancer statistics, 2021. CA Cancer J. Clin. 2021, 71, 7-33. [CrossRef]

4. Sung, H.; Ferlay, J.; Siegel, R.L.; Laversanne, M.; Soerjomataram, I.; Jemal, A.; Bray, F. Global cancer statistics 2020: Globocan estimates of incidence and mortality worldwide for 36 cancers in 185 countries. CA Cancer J. Clin. 2021, 71, 209-249. [CrossRef] [PubMed]

5. Naso, L.G.; Ferrer, E.G.; Lezama, L.; Rojo, T.; Etcheverry, S.B.; Williams, P.A.M. Role of oxidative stress in the antitumoral action of a new vanadyl(IV) complex with the flavonoid chrysin in two osteoblast cell lines: Relationship with the radical scavenger activity. J. Biol. Inorg. Chem. 2010, 15, 889-902. [CrossRef]

6. Naso, L.G.; Valcarcel, M.; Villace, P.; Roura-Ferrer, M.; Salado, C.; Ferrer, E.G.; Williams, P.A.M. Specific antitumor activities of natural and oxovanadium(IV) complexed flavonoids in human breast cancer cells. New J. Chem. 2014, 38, 2414-2421. [CrossRef]

7. Naso, L.G.; Martínez Medina, J.J.; Okulik, N.B.; Ferrer, E.G.; Williams, P.A.M. Study on the cytotoxic, antimetastatic and albumin binding properties of the oxidovanadium(IV) chrysin complex. Structural elucidation by computational methodologies. Chem. Biol. Interact. 2022, 351, 109750. [CrossRef] [PubMed]

8. Naso, L.G.; Martínez Medina, J.J.; D’Alessandro, F.; Rey, M.; Rizzi, A.; Piro, O.E.; Echeverría, G.A.; Ferrer, E.G.; Williams, P.A.M. Ternary Copper(II) complex of 5-hydroxytryptophan and 1,10-phenanthroline with several pharmacological properties and an adequate safety profile. J. Inorg. Biochem. 2020, 204, 110933. [CrossRef]

9. Halevas, E.; Mavroidi, B.; Antonoglou, O.; Hatzidimitriou, A.; Sagnou, M.; Pantazaki, A.A.; Litsardakis, G.; Pelecanou, M. Structurally characterized gallium-chrysin complexes with anticancer potential. Dalton Trans. 2020, 49, 2734-2746. [CrossRef] [PubMed]

10. Halevas, E.; Mitrakas, A.; Mavroidi, B.; Athanasiou, D.; Gkika, P.; Antoniou, K.; Samaras, G.; Lialiaris, E.; Hatzidimitriou, A.; Pantazaki, A.; et al. Structurally characterized copper-chrysin complexes display genotoxic and cytotoxic activity in human cells. Inorg. Chim. Acta 2021, 515, 120062. [CrossRef]

11. Zahirović, A.; Kahrović, E.; Cindrić, M.; Kraljević Pavelić, S.; Hukić, M.; Harej, A.; Turkušić, E. Heteroleptic ruthenium bioflavonoid complexes: From synthesis to in vitro biological activity. J. Coord. Chem. 2017, 24, 4030-4053. [CrossRef]

12. Islas, M.S.; Martínez Medina, J.J.; Piro, O.E.; Echeverría, G.A.; Ferrer, E.G.; Williams, P.A.M. Comparisons of the spectroscopic and microbiological activities among coumarin-3-carboxylate, o-phenanthroline and zinc(II) complexes. Spectrochim. Acta A 2018, 198, 212-221. [CrossRef]

13. Rizzi, A.C.; Neuman, N.I.; González, P.J.; Brondino, C.D. EPR as a Tool for Study of Isolated and Coupled Paramagnetic Centers in Coordination Compounds and Macromolecules of Biological Interest. Eur. J. Inorg. Chem. 2016, 2, 192-207. [CrossRef]

14. Ferrer, E.G.; Salinas, M.V.; Correa, M.J.; Naso, L.; Barrio, D.A.; Etcheverry, S.B.; Lezama, L.; Rojo, T.; Williams, P.A.M. Synthesis, characterization, antitumoral and osteogenic activities of Quercetin vanadyl(IV) complexes. J. Biol. Inorg. Chem. 2006, 11, 791-801. [CrossRef] [PubMed]

15. Martínez Medina, J.J.; Naso, L.G.; Pérez, A.L.; Rizzi, A.; Okulik, N.B.; Ferrer, E.G.; Williams, P.A.M. Apigenin oxidovanadium(IV) cation interactions. Synthesis, spectral, bovine serum albumin binding, antioxidant and anticancer studies. J. Photochem. Photobiol. A 2017, 344, 84-100. [CrossRef]

16. Islas, M.S.; Naso, L.G.; Lezama, L.; Valcarcel, M.; Salado, C.; Roura-Ferrer, M.; Ferrer, E.G.; Williams, P.A.M. Insights into the mechanisms underlying the antitumor activity of an oxidovanadium(IV) compound with the antioxidant naringenin. Albumin binding studies. J. Inorg. Biochem. 2015, 149, 12-24. [CrossRef]

17. Chasteen, N.D. Vanadyl(IV) EPR Spin Probe. Inorganic and Biochemical Aspects. In Biological Magnetic Resonance; Berliner, L.J., Reuben, J., Eds.; Plenum Press: New York, NY, USA, 1981; Volume 3, pp. 53-119.

18. Benítez, J.; Becco, L.; Correia, I.; Leal, S.M.; Guiset, H.; Costa Pessoa, J.; Lorenzo, J.; Tanco, S.; Escobar, P.; Moreno, V.; et al. Vanadium polypyridyl compounds as potential antiparasitic and antitumoral agents: New achievements. J. Inorg. Biochem. 2011, 105, 303-312. [CrossRef]

19. Kivelson, D.; Lee, S.J. ESR Studies and the Electronic Structure of Vanadyl Ion Complexes. Chem. Phys. 1964, 41, 1896-1903. [CrossRef] 
20. Chand, P.; Murali Krishna, R.; Lakshamana Rao, J.; Lakshaman, S.V.J. EPR and optical studies of vanadyl complexes in two host-crystals of Tutton salts of thallium. Rad. Eff. Def. Solids 1993, 127, 245-254. [CrossRef]

21. Liu, K.T.; Yu, J.T.; Lou, S.H.; Lee, C.H.; Huang, Y.; Lii, K.H. Electron paramagnetic resonance study of $\mathrm{V}^{4+}$-doped $\mathrm{KTiOPO}_{4}$ single crystals. J. Phys. Chem. Solids 1994, 55, 1221-1226. [CrossRef]

22. Bandyopadhyay, A.K. Optical and ESR investigation of borate glasses containing single and mixed transition metal oxides. J. Mater. Sci. 1981, 16, 189-203. [CrossRef]

23. Nunes, P.; Correia, I.; Cavaco, I.; Marques, F.; Pinheiro, T.; Avecilla, F.; Pessoa, J.C. Therapeutic potential of vanadium complexes with 1,10-phenanthroline ligands, quo vadis? Fate of complexes in cell media and cancer cells. J. Inorg. Biochem. 2021, $217,111350$. [CrossRef]

24. Holko, P.; Ligęza, J.; Kisielewska, J.; Kordowiak, A.M.; Klein, A. The Effect of Vanadyl Sulphate $\left(V_{O S O}\right)$ on Autocrine Growth of Human Epithelial Cancer Cell Lines Pol. J. Pathol. 2008, 59, 3-8.

25. Wu, B.L.; Wu, Z.W.; Yang, F.; Shen, X.F.; Wang, L.; Chen, B.; Li, F.; Wang, M.K. Flavonoids from the seeds of Oroxylum indicum and their anti-inflammatory and cytotoxic activities. Phytochem. Lett. 2019, 32, 66-69. [CrossRef]

26. Kumar, N.; Afjei, R.; Massoud, T.F.; Paulmurugan, R. Comparison of cell-based assays to quantify treatment effects of anticancer drugs identifies a new application for Bodipy-L-cystine to measure apoptosis. Sci. Rep. 2018, 8, 16363. [CrossRef]

27. Guerrero-Palomo, G.; Rendón-Huerta, E.P.; Montaño, L.F.; Fortoul, T.I. Vanadium compounds and cellular death mechanisms in the A549 cell line: The relevance of the compound valence. J. Appl. Toxicol. 2019, 39, 540-552. [CrossRef] [PubMed]

28. Zitka, O.; Skalickova, S.; Gumulec, J.; Masarik, M.; Adam, V.; Hubalek, J.; Trnkova, L.; Kruseova, J.; Eckschlager, T.; Kizek, R. Redox status expressed as GSH:GSSG ratio as a marker for oxidative stress in paediatric tumour patients. Onc. Lett. 2012, 4, 1247-1253. [CrossRef]

29. Matsuyama, S.; Reed, J.C. Mitochondria-dependent apoptosis and cellular pH regulation. Cell Death Differ. 2000, 7, $1155-1165$. [CrossRef]

30. Perry, S.W.; Norman, J.P.; Barbieri, J.; Brown, E.B.; Gelbard, H.A. Mitochondrial membrane potential probes and the proton gradient: A practical usage guide. Biotechniques 2011, 50, 98-115. [CrossRef] [PubMed]

31. Correia, I.; Chorna, L.; Cavaco, I.; Roy, S.; Kuznetsov, M.; Ribeiro, N.; Justino, G.; Santos-Silva, T.; Santos, M.; Santos, H.; et al. Interaction of $\left[\mathrm{V}^{\mathrm{IV}} \mathrm{O}(\mathrm{acac})_{2}\right]$ with Human Serum Transferrin and Albumin. Chem. Asian J. 2017, 12, 2062-2084. [CrossRef]

32. Chadborn, N.; Bryant, J.; Bain, A.J.; O'Shea, P. Ligand-dependent conformational equilibria of serum albumin revealed by tryptophan fluorescence quenching. Biophys. J. 1999, 76, 2198-2207. [CrossRef]

33. Lakowicz, J.R. Principles of Fluorescence Spectroscopy; Springer Science \& Business Media: New York, NY, USA, 2013.

34. Ross, P.D.; Subramanian, S. Thermodynamics of protein association reactions: Forces contributing to stability. Biochemistry 1981, 20, 3096-3102. [CrossRef]

35. Costa Pessoa, J.; Correia, I. Misinterpretations in Evaluating Interactions of Vanadium Complexes with Proteins and Other Biological Targets. Inorganics 2021, 9, 17. [CrossRef]

36. Le, M.; Rathje, O.; Levina, A.; Lay, P. High cytotoxicity of vanadium(IV) complexes with 1,10-phenanthroline and related ligands is due to decomposition in cell culture medium. J. Biol. Inorg. Chem. 2017, 22, 663-672. [CrossRef]

37. Shan, F.; Shao, Z.; Jiang, S.; Cheng, Z. Erlotinib induces the human non-small-cell lung cancer cells apoptosis via activating ROS-dependent JNK pathways. Cancer Med. 2016, 11, 3166-3175. [CrossRef]

38. Onishi, M. Photometric Determination of Traces of Metals, 4th ed.; Wiley: NewYork, NY, USA, 1989.

39. Stoll, S.; Schweiger, A. EasySpin, a comprehensive software package for spectral simulation and analysis in EPR. J. Magn. Reson. 2006, 178, 42-55. [CrossRef]

40. Ling, L.; Tan, K.; Lin, H.; Chiu, G. The role of reactive oxygen species and autophagy in safingol-induced cell death. Cell Death Dis. 2011, 2, e129. [CrossRef] [PubMed]

41. Hissin, P.J.; Hilf, R.A. Fluorometric Method for Determination of Oxidized and Reduced Glutathione in Tissues. Anal. Biochem. 1976, 74, 214-226. [CrossRef]

42. Bradford, M.A. Rapid and Sensitive Method for the Quantitation of Microgram Quantities of Protein Utilizing the Principle of Protein-Dye Binding. Anal. Biochem. 1976, 72, 248-254. [CrossRef]

43. Zamzami, N.; Métivier, D.; Kroemer, G. Quantitation of Mitochondrial Transmembrane Potential in Cells and in Isolated Mitochondria. Methods Enzymol. 2000, 322, 208-213. [CrossRef] [PubMed]

44. Levina, A.; Pires Vieira, A.; Wijetunga, A.; Kaur, R.; Koehn, J.; Crans, D.; Lay, P. A Short-Lived but Highly Cytotoxic Vanadium(V) Complex as a Potential Drug Lead for Brain Cancer Treatment by Intratumoral Injections. Angew. Chem. 2020, 59, 15834-15838. [CrossRef] 